\title{
Ruthenium/TFA-catalyzed regioselective C-3-alkylation of indoles with terminal alkynes in water: efficient and unprecedented access to 3-(1-methylalkyl)-1H-indoles $\dagger$
}

\author{
Victorio Cadierno,* Javier Francos and José Gimeno* \\ Received 9th February 2010, Accepted 9th April 2010 \\ First published as an Advance Article on the web 28th April 2010 \\ DOI: $10.1039 / \mathrm{c002804e}$
}

An unprecedented C-3-alkylation reaction of indoles with terminal alkynes in aqueous medium has been developed using catalytic amounts of ruthenium and trifluoroacetic acid.

The search for new efficient and selective synthetic methods to indoles continues to receive considerable attention since they are key structural units in a huge number of natural products and biologically active molecules. ${ }^{1}$ In this context, the well-known nucleophilic nature of indolyl compounds, particularly at the C-3 position, ${ }^{2}$ makes derivatization of the preformed heteroaromatic ring one of the most useful approaches to generate functionalized derivatives. ${ }^{3}$ Among the different ways to perform the alkylation of indoles, the 1,2-addition to carbonyl compounds and imines, the Michael-type reactions with electron-deficient olefins, the ring-opening of epoxides and aziridines, and the well-known Pd-catalyzed allylic substitution processes (Tsuji-Trost reaction), are probably the most powerful and versatile ones. ${ }^{4,5}$

Recent studies have shown that indoles can also be alkylated using alkynes as electrophiles, ${ }^{6}$ via metal-catalyzed hydroarylation of the $\mathrm{C} \equiv \mathrm{C}$ bond, ${ }^{7}$ the intermolecular version of this process giving an expeditious access to both 3-alkenylindoles (A) and bis(indolyl)alkanes (B) (Scheme 1).

However, despite its enormous synthetic potential, to date efficient catalysts available for these transformations are very scarce (mainly $\mathrm{Ga}(\mathrm{III}), \mathrm{Pt}(\mathrm{II}), \mathrm{Au}(\mathrm{I})$ and $\mathrm{Au}(\mathrm{III})$ derivatives). ${ }^{6}$ This fact, along with our current interest in the application of ruthenium catalysts in heterocyclic chemistry, ${ }^{8}$ encouraged us to study the suitability of ruthenium to promote alkylation reactions of indoles with alkynes. ${ }^{9,10}$ In the context of these studies, a surprising and unprecedented result was encountered by performing the catalytic reactions in aqueous medium, ${ }^{11}$ and in the presence of trifluoroacetic acid (TFA). Thus, as

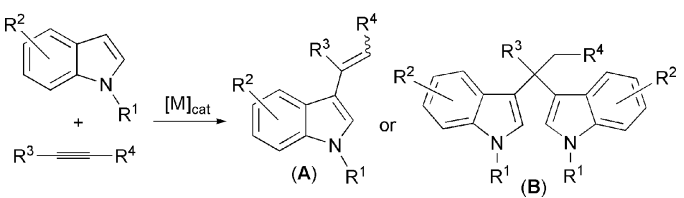

Scheme 1 Metal-catalyzed alkylations of indoles with alkynes.

Departamento de Química Orgánica e Inorgánica. IUQOEM, University of Oviedo, E-33006 Oviedo, Spain.E-mail:vcm@uniovi.es, jgh@uniovi.es; Fax: (+34)985103446; Tel: (+34)985102985

$\dagger$ Electronic supplementary information (ESI) available: Characterization data and copies of the NMR spectra of all compounds. See DOI: 10.1039/ c002804e
Table 1 Ruthenium-catalyzed alkylation of indole with 1-hexyne ${ }^{a}$

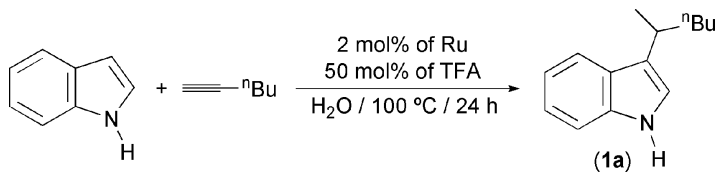

(1a) $\mathrm{H}$

\begin{tabular}{llll}
\hline Entry & Catalyst & Conversion $^{b}$ & Yield $^{b}$ \\
\hline 1 & {$\left[\left\{\mathrm{RuCl}(\mu-\mathrm{Cl})\left(\eta^{6}-\mathrm{C}_{6} \mathrm{Me}_{6}\right)\right\}_{2}\right]$} & $57 \%$ & $48 \%$ \\
2 & {$\left[\left\{\mathrm{RuCl}(\mu-\mathrm{Cl})\left(\eta^{6}-1,3,5-\mathrm{C}_{6} \mathrm{H}_{3} \mathrm{Me}_{3}\right)\right\}_{2}\right]$} & $93 \%$ & $86 \%$ \\
3 & {$\left[\left\{\mathrm{RuCl}(\mu-\mathrm{Cl})\left(\eta^{6}-p-\mathrm{cymen}_{2}\right)\right\}_{2}\right]$} & $95 \%$ & $91 \%$ \\
4 & {$\left[\left\{\mathrm{RuCl}(\mu-\mathrm{Cl})\left(\eta^{6}-\mathrm{C}_{6} \mathrm{H}_{6}\right)\right\}_{2}\right]$} & $87 \%$ & $81 \%$ \\
5 & {$\left[\mathrm{RuCl}\left(\mathrm{PPh}_{3}\right)_{3}\right]$} & $91 \%$ & $70 \%$ \\
6 & {$\left[\mathrm{Ru}\left(\eta^{3}-2-\mathrm{C}_{3} \mathrm{H}_{4} \mathrm{Me}\right)_{2}(\mathrm{COD})\right]$} & $85 \%$ & $85 \%$ \\
7 & {$\left[\mathrm{RuCl}\left(\mathrm{DMSO}_{4}\right]\right.$} & $90 \%$ & $82 \%$ \\
8 & {$\left[\mathrm{RuCl}\left(\eta^{5}-\mathrm{C}_{5} \mathrm{H}_{5}\right)\left(\mathrm{PPh}_{3}\right)_{2}\right]$} & $89 \%$ & $81 \%$ \\
9 & {$\left[\mathrm{RuCl}\left(\eta^{5}-\mathrm{C}_{9} \mathrm{H}_{7}\right)\left(\mathrm{PPh}_{3}\right)_{2}\right]$} & $86 \%$ & $73 \%$ \\
10 & $\mathrm{RuCl} \cdot n \mathrm{H}_{2} \mathrm{O}$ & $90 \%$ & $82 \%$ \\
11 & {$\left[\mathrm{RuCl} \mathrm{O}_{2}\left(\eta^{3}: \eta^{2}: \eta^{3}-\mathrm{C}_{12} \mathrm{H}_{18}\right)\right]$} & $99 \%$ & $77 \%$ \\
12 & {$\left[\left\{\mathrm{RuCl}(\mu-\mathrm{Cl})\left(\eta^{3}: \eta^{3}-\mathrm{C}_{10} \mathrm{H}_{16}\right)\right\}_{2}\right]$} & $99 \%$ & $94 \%$
\end{tabular}

${ }^{a}$ Reactions performed under an $\mathrm{N}_{2}$ atmosphere at $100{ }^{\circ} \mathrm{C}$ using $1 \mathrm{mmol}$ of indole (1 M solution in water) and $2.5 \mathrm{mmol}$ of 1-hexyne. [Indole]: [alkyne]:[Ru]:[TFA] ratio $=100: 250: 2: 50 .^{b}$ Determined by GC.

shown in Table 1, treatment of indole with excess of 1-hexyne ( 2.5 equiv.) in water at $100{ }^{\circ} \mathrm{C}$ led, in the presence of usual ruthenium complexes ( $2 \mathrm{~mol} \%$ of $\mathrm{Ru})$ and TFA ( $50 \mathrm{~mol} \%)$, to the high yield formation of 3-(1-methylpentyl)- $H$-indole (1a) ${ }^{12}$ instead of the corresponding 3-alkenyl-indole $\mathbf{A}$ or bis(indolyl)alkane $\mathbf{B} .{ }^{13}$ No influence of the oxidation state of the metal on the reaction outcome was noted, both $\mathrm{Ru}(\mathrm{II})$ (entries 1-9), Ru(III) (entry 10) and Ru(IV) (entries 11-12) precatalysts being operative. Among them, the best result was obtained with the bis(allyl)-ruthenium(Iv) dimer $\left[\left\{\mathrm{RuCl}(\mu-\mathrm{Cl})\left(\eta^{3}: \eta^{3}-\mathrm{C}_{10} \mathrm{H}_{16}\right)\right\}_{2}\right],{ }^{14}$ which afforded 1a in $94 \%$ GC-yield after $24 \mathrm{~h}$ of heating (entry 12). Subsequent purification by column chromatography on silica gel provided an analytically pure sample of this alkylated indole in $84 \%$ isolated yield.

At this point, the following observations are of note: $(i)$ the process is regioselective with respect to the indole, $N$ - or $C$-2-substituted products not being observed in the crude reaction mixtures, $(i i)$ the process is also regioselective with respect to the alkyne, i.e. the Markovnikov addition product is formed exclusively regardless of the catalyst employed, (iii) the use of water as solvent is imperative, 1a being not formed in organic media (refluxing toluene, THF or $\mathrm{CH}_{2} \mathrm{Cl}_{2}$ solutions), (iv) the use of lower temperatures and/or TFA loadings reduces the yield of $\mathbf{1 a}$ and slows down the reaction considerably, 
Table 2 Scope of the alkylation reaction of indoles with terminal alkynes catalyzed by complex $\left[\left\{\mathrm{RuCl}(\mu-\mathrm{Cl})\left(\eta^{3}: \eta^{3}-\mathrm{C}_{10} \mathrm{H}_{16}\right)\right\}_{2}\right]$ in water ${ }^{a}$

$$
\text { 年 }
$$

\begin{tabular}{|c|c|c|c|c|c|c|c|c|}
\hline Entry & Indole & Alkyne & Product & Yield $^{b}$ & Entry & Indole & Alkyne & Product \\
\hline 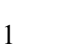 & & & & $84 \%$ & 11 & & & \\
\hline
\end{tabular}

Yield $^{b}$

2<smiles>C#CCCC</smiles><smiles>CCCC(C)c1c[nH]c2ccccc12</smiles>

3<smiles>C#CCOC</smiles><smiles>CCCC(C)c1c[nH]c2ccccc12</smiles><smiles>C#CCOC</smiles><smiles>CCCC(C)c1c[nH]c2ccccc12</smiles><smiles>C#CCC(C)C</smiles><smiles>c1ccc2[nH]ccc2c1</smiles><smiles>C#CC1CCCCC1</smiles><smiles>CC(C)CC(C)c1cn(C)c2ccccc12</smiles>

6

7<smiles>C#CCC1CCCC1</smiles><smiles>CC(c1c[nH]c2ccccc12)C1CCCCC1</smiles>

$64 \%$

$79 \%$

12<smiles>Nc1ccc2[nH]ccc2c1</smiles><smiles>C#CCCCC</smiles>

$76 \%$

13<smiles>COc1ccc2[nH]ccc2c1</smiles><smiles>C#CCCCC</smiles><smiles>CCCCC(C)c1c[nH]c2ccc(C)cc12</smiles>

$82 \%$

$57 \% \quad 14$<smiles>Fc1ccc2[nH]ccc2c1</smiles><smiles>C#CCCCC</smiles><smiles>CCCCC(C)c1c[nH]c2ccc(OC)cc12</smiles>

$79 \%$

$69 \%$<smiles>CCCCC(C)c1c[nH]c2ccc(F)cc12</smiles><smiles>C#CCCCC</smiles><smiles>CCCCC(C)c1c[nH]c2ccc(Cl)cc12</smiles>

$67 \%$

$69 \% \quad 16$<smiles>Brc1ccc2[nH]ccc2c1</smiles><smiles>C#CCCCCC</smiles><smiles>CCCCC(C)c1c[nH]c2ccc(Br)cc12</smiles><smiles>C#CCCCCC</smiles><smiles>CCCCC(C)c1c[nH]c2ccc(I)cc12</smiles>

$82 \%$<smiles>Ic1ccc2[nH]ccc2c1</smiles><smiles>COC(=O)c1ccc2[nH]ccc2c1</smiles><smiles>C#CCCCCCC</smiles><smiles>CCCCC(C)c1c[nH]c2ccc(C(=O)OC)cc12</smiles>

$87 \%$<smiles></smiles><smiles>C#CCCCCC</smiles><smiles>CCCCC(C)c1c[nH]c2c([N+](=O)[O-])cccc12</smiles>

$60 \%$<smiles>C#CCCCc1ccccc1</smiles><smiles>CC(CCCc1ccccc1)c1c[nH]c2ccccc12</smiles>

$60 \%$<smiles>CC(c1ccccc1)c1c[nH]c2ccccc12</smiles>

$0 \%$

20<smiles>Clc1ccc2cc[nH]c2c1</smiles><smiles>C#CCCCC</smiles><smiles>CCCCC(C)c1c[nH]c2cc(Cl)ccc12</smiles>

$65 \%$

${ }^{a}$ Reactions performed under an $\mathrm{N}_{2}$ atmosphere at $100{ }^{\circ} \mathrm{C}$ using $1 \mathrm{mmol}$ of the corresponding indole ( $1 \mathrm{M}$ solution in water) and $2.5 \mathrm{mmol}$ of the appropriate terminal alkyne. [Indole] : [alkyne]:[Ru]:[TFA] ratio $=100: 250: 2: 50 .{ }^{b}$ Isolated yield after chromatographic work-up.

and $(v)$ the excess of 1-hexyne present in the reaction medium is totally consumed during the catalytic reaction. ${ }^{13}$ In addition, when a stoichiometric amount of 1-hexyne was used (indole: alkyne ratio $=1: 1$ ) the yield of 1a also decreased, recovering part of the indole unchanged.

Using complex $\left[\left\{\mathrm{RuCl}(\mu-\mathrm{Cl})\left(\eta^{3}: \eta^{3}-\mathrm{C}_{10} \mathrm{H}_{16}\right)\right\}_{2}\right]$ the scope of this unusual alkylation reaction was explored (see Table 2). $\ddagger$
The generality with respect to the terminal alkyne was firstly evaluated. Thus, as observed for 1-hexyne (entry 1), other aliphatic alkynes (entries 2-9) were able to couple with indole, the resulting 3-(1-methylalkyl)- $1 H$-indoles $\mathbf{1 b}-\mathbf{i}$ being isolated in moderate to good yields $(57-83 \%)$ after $24 \mathrm{~h}$ of heating. In contrast, starting from aromatic substrates, such as phenylacetylene or $p$-tolylacetylene, mixtures containing the expected 


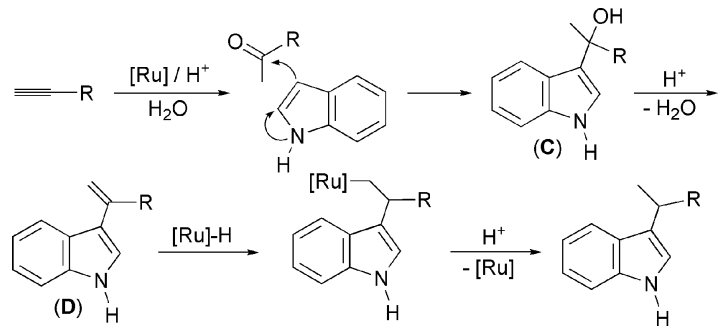

Scheme 2 Proposed mechanism.

alkylated indoles, albeit in very low yields ( $c a$. 15\%; GC-MS determined), were obtained. The major formation of several uncharacterized by-products prevented in these cases the isolation of the desired products (entries 10-11).

The compatibility of this $\mathrm{C}-\mathrm{C}$ coupling reaction with other indolyl derivatives was also investigated. Thus, as shown in entries 12-20, several $\mathrm{NH}$-indoles substituted at the benzenoid moiety could be effectively alkylated with 1-hexyne to afford the novel compounds $\mathbf{1} \mathbf{j}-\mathbf{r}$ in $57-87 \%$ yield. No remarkable influence of the position and electronic nature of the substituents was observed.

A tentative mechanistic proposal explaining the formation of $\mathbf{1 a}-\mathbf{r}$ is depicted in Scheme 2. Initially, a Ru-catalyzed Markovnikov hydration of the alkyne, a process favoured in acidic media, ${ }^{15}$ takes place, generating a methyl ketone which readily undergoes 1,2-addition of the indolyl unit. ${ }^{13 b}$ Then, an acid-catalyzed dehydration of the resulting alcohol $\mathbf{C}$ probably occurs leading to the 3 -alkenyl intermediate $\mathbf{D} .{ }^{16}$ Final reduction of the $\mathbf{C}=\mathrm{C}$ bond of $\mathbf{D}$ by in situ formed $\mathrm{Ru}$-hydride species delivers the observed products. ${ }^{17}$

In summary, an unprecedented and high-yielding procedure for the regioselective C-3 alkylation of indoles with alkynes in aqueous medium has been developed. Further studies aimed at clarifying the mechanism of this catalytic process and broadening its scope to the alkylation of other heteroaromatic substrates (pyrroles, furans, benzofurans, etc.) are currently in progress in our lab.

This work was supported by MICINN (Projects CTQ2006-08485/BQU and CSD2007-00006) and FICYT (Project IB08-036). J.F. thanks MICINN and the ESF for the award of a PhD grant.

\section{Notes and references}

$\ddagger$ General procedure for the catalytic reactions: the corresponding indole $(1 \mathrm{mmol})$, the appropriate terminal alkyne $(2.5 \mathrm{mmol})$ and water $\left(1 \mathrm{~cm}^{3}\right)$ were introduced into a sealed tube under a nitrogen atmosphere. $\left[\left\{\mathrm{RuCl}(\mu-\mathrm{Cl})\left(\eta^{3}: \eta^{3}-\mathrm{C}_{10} \mathrm{H}_{16}\right)\right\}_{2}\right] \quad(0.006 \mathrm{~g}, 0.01 \mathrm{mmol}$; $2 \mathrm{~mol} \%$ of $\mathrm{Ru})$ and TFA $\left(0.037 \mathrm{~cm}^{3}, 0.5 \mathrm{mmol}\right)$ were then added at room temperature, and the resulting suspension heated at $100{ }^{\circ} \mathrm{C}$ for $24 \mathrm{~h}$. After removal of the volatiles under vacuum, the residue was purified by column chromatography (silica gel) using a mixture of EtOAc/hexanes $(1: 50)$ as eluent.

1 See, for example: (a) R. J. Sundberg, Indoles, Academic Press, San Diego, 1996; (b) K. Higuchi and T. Kawasaki, Nat. Prod. Rep., 2007, 24, 843; (c) S.-M. Li, Nat. Prod. Rep., 2010, $27,57$.

2 S. Lakhdar, M. Westermaier, F. Terrier, R. Goumont, T. Boubaker, A. R. Ofial and H. Mayr, J. Org. Chem., 2006, 71, 9088.

3 (a) B. A. Trofimov and N. A. Nedolya, in Comprehensive Heterocyclic Chemistry III, ed. A. R. Katritzky, C. A. Ramsden, E. F. V. Scriven and R. J. K. Taylor, Elsevier, Oxford, 2008, vol. 3, pp. 45-268; (b) J. Bergman and T. Janosic, in Comprehensive Heterocyclic Chemistry III, ed. A. R. Katritzky, C. A. Ramsden,
E. F. V. Scriven and R. J. K. Taylor, Elsevier, Oxford, 2008, vol. 3, pp. 269-351

4 (a) S.-L. You, Q. Cai and M. Zeng, Chem. Soc. Rev., 2009, 38, 2190; (b) T. B. Poulsen and K. A. Jørgensen, Chem. Rev., 2008, 108, 2903; (c) N. Saracoglu, Top. Heterocycl. Chem., 2007, 11, 1; (d) M. Bandini, A. Melloni, S. Tommasi and A. Umani-Ronchi, Synlett, 2005, 1199; (e) S. Cacchi and G. Fabrizi, Chem. Rev., 2005, 105, 2873.

5 Alkylation of indoles with alcohols using transition metal- and Lewis or Brønsted acid-catalyzed methodologies has also emerged as an area of intense activity in recent years: R. Sanz, D. Miguel, J. M. Álvarez-Gutiérrez and F. Rodríguez, Synlett, 2008, 975 and references cited therein.

6 See, for example: (a) J. S. Yadav, B. V. S. Reddy, B. Padmavani and M. K. Gupta, Tetrahedron Lett., 2004, 45, 7577; (b) V. Mamane, P. Hannen and A. Fürstner, Chem.-Eur. J., 2004, 10, 4556; (c) C. Ferrer and A. M. Echavarren, Angew. Chem., Int. Ed., 2006, 45, 1105; (d) Y. Zhang, Tetrahedron, 2006, 62, 3917; (e) C. Ferrer, C. H. M. Amijs and A. M. Echavarren, Chem.-Eur. J., 2007, 13, 1358; (f) S. B. Bhuvaneswari, M. Jeganmohan and C.-H. Cheng, Chem.-Eur. J., 2007, 13, 8285; (g) J. Barluenga, A. Fernández, F. Rodríguez and F. J. Fañanas, J. Organomet. Chem., 2009, 694, 546.

7 For a general review on the hydroarylation of alkynes, see: C. Nevado and A. M. Echavarren, Synthesis, 2005, 167.

8 (a) V. Cadierno, J. Gimeno and N. Nebra, Adv. Synth. Catal., 2007, 349, 382; (b) V. Cadierno, J. Gimeno and N. Nebra, Chem.-Eur. J., 2007, 13, 9973; (c) V. Cadierno, J. Díez, J. Gimeno and N. Nebra, J. Org. Chem., 2008, 73, 5852; (d) V. Cadierno, J. Gimeno and N. Nebra, J. Heterocycl. Chem., 2010, 47, 233.

9 The utility of Ru catalysts to promote selective transformations of alkynes has been largely demonstrated: (a) B. M. Trost, M. U. Frederiksen and M. T. Rudd, Angew. Chem., Int. Ed., 2005, 44, 6630; (b) C. Bruneau and P. H. Dixneuf, Angew. Chem., Int. Ed., 2006, 45, 2176; (c) B. M. Trost and A. McClory, Chem.-Asian J., 2008, 3, 164.

$10 \mathrm{Ru}$-catalyzed hydroarylations of alkynes are scarce, being mainly restricted to intramolecular processes. See ref. 7.

11 The development of organic transformations in aqueous media is a topic of primary interest in modern chemistry: $(a)$ C.-J. Li and T. H. Chan, Comprehensive Organic Reactions in Aqueous Media, John Wiley \& Sons, Hoboken, 2007; (b) Organic Reactions in Water: Principles, Strategies and Applications, ed. U. M. Lindstrom, Blackwell Publishing Ltd, Oxford, 2007; (c) L. Chen and C.-J. Li, Adv. Synth. Catal., 2006, 348, 1459.

12 A.-M. L. Hogan and D. F. O'Shea, J. Org. Chem., 2008, 73, 2503.

13 (a) Alkyne oligomers as well as minor amounts of a by-product, whose mass spectrum could correspond to the bis(indolyl) derivative 2 (MS (EI, $70 \mathrm{eV}): m / z 316\left(\mathrm{M}^{+}, 10 \%\right), 301\left(\mathrm{M}^{+}-\mathrm{Me}, 5 \%\right)$, $\left.259\left(\mathrm{M}^{+}-\mathrm{Bu}, 100 \%\right), 243\left(\mathrm{M}^{+}-\mathrm{Me}-\mathrm{Bu}, 10 \%\right)\right)$, were detected in the crude reaction mixtures by ${ }^{1} \mathrm{H}$ NMR spectroscopy and GC/MSD. Formation of $\mathbf{2}$ is responsible for the difference observed between indole conversion and product yield; (b) Intermediate formation of hexan-2-one was observed by monitoring the reaction of indole with 1-hexyne by GC/MSD

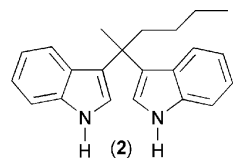

14 For a review on this dimer, see: V. Cadierno, P. Crochet, S. E. García-Garrido and J. Gimeno, Curr. Org. Chem., 2006, 10, 165.

15 F. Alonso, I. P. Beletskaya and M. Yus, Chem. Rev., 2004, 104 3079 .

16 Addition of a second molecule of indole to intermediate $\mathbf{D}$ could explain the formation of the side-product 2.

17 These hydride species, presumably generated from the excess of terminal alkyne present via oxidative addition to $\mathrm{Ru}(\mathrm{II})$ centres, could also be responsible for the alkyne oligomers observed. We note that $\mathrm{Ru}(\mathrm{IV}) / \mathrm{Ru}(\mathrm{II})$ reductions are well-known in the chemistry of $\left[\left\{\mathrm{RuCl}(\mu-\mathrm{Cl})\left(\eta^{3}: \eta^{3}-\mathrm{C}_{10} \mathrm{H}_{16}\right)\right\}_{2}\right]$. See ref. 14 and V. Cadierno, S. E. García-Garrido and J. Gimeno, J. Am. Chem. Soc., 2006, 128, 15094. 